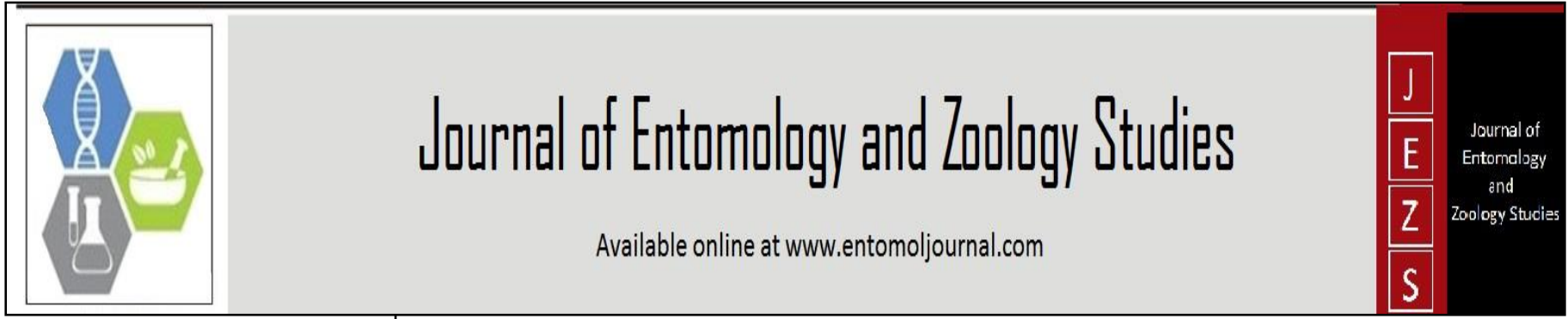

E-ISSN: 2320-7078

P-ISSN: 2349-6800

www.entomoljournal.com

JEZS 2020; 8(6): 302-307

(C) 2020 JEZS

Received: 12-09-2020

Accepted: 21-10-2020

Mohamed Alaaeldein Mohamed Elmorsy Ph.D., Scholar, Department of Veterinary Clinical Medicine, College of Veterinary Science and Animal Husbandry, Odisha University of Agriculture and Technology, CVSc \& AH, OUAT, Bhubaneswar, Odis, India.

Geeta Rani Jena

Assistant Professor, Department of Veterinary Clinical Medicine, College of Veterinary Science and Aniul Ho of Odisa Univerity of A riolturea Te hatog, CVS \& AH, OUAT, Bhubaneswar, Odisha, Indi

Susen Kumar Panda

Professor and Head, Department of

Pathology, College of Veterinary Scie

and Animal Husbandry, Odisha University

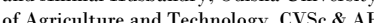

OUAT, Bhubaneswar, Odisha, India

Akshaya Kumar Kundo

Professor and Head, Department of

Veterinary Physiology, College of

Veterinary Science and Animal Husbandry,

Odisha University of Agriculture and

Technology, CVSc \& AH, OUAT,

Bhubaneswar, Odisha, India

Dhirendra Kumar

Scientist, Regional Centre, ICAR-

Directorate of poultry Research

Bhubaneswar, Odisha, India

Suryakant Mishra

Principal Scientist, Regional Centre, ICARDirectorate of Poultry Research,

Bhubaneswar, Odisha, India

Santosh Kumar Senapati

Associate Professor, Department of

Veterinary Clinical Medicine, College of

Veterinary Science and Animal Husbandry,

Odisha University of Agriculture and

Technology, CVSc \& AH, OUAT,

Bhubaneswar, Odisha, India

Chinmaya Majhi

M.V.Sc. Scholar, Department of Veterinary

Clinical Medicine, College of Veterinary

Science and Animal Husbandry, Odisha

University of Agriculture and Technology,

CVSc \& AH, OUAT, Bhubaneswar, Odisha,

India

Santosh Kumar Panda

M.V.Sc. Scholar, Department of Veterinary Clinical Medicine, College of Veterinary Science and Animal Husbandry, Odisha University of Agriculture and Technology, CVSc \& AH, OUAT, Bhubaneswar, Odish, India

Manoranjan Das

Professor and Head, Department of Veterinary Clinical Medicine, College of Veterinary Science a d A Oding Unive Te hiolog, ar, Odisha, Ind

Corresponding Author:

Mohamed Alaaeldein Mohamed Elmor $\mathrm{Ph}$ D. Schar, Depar Chibuch Clinical Medicine, Colloge of Veterinary Science and Animal Husbandry, Odisha University of Agriculture and Technology, Bhubaneswar, Odisha, India

\section{Isolation, identification, and clinical impact of coccidiosis in Japanese quail farms in and around Bhubaneswar, Odisha, India}

\author{
MA Elmorsy, GR Jena, SK Panda, AK Kundo, D Kumar, SK Mishra, SK \\ Senapati, C Majhi, SK Panda and MR Das
}

DOI: https://doi.org/10.22271/j.ento.2020.v8.i6d.7870

\section{Abstract}

This study was carried out to isolate and identify different Eimeria species of Japanese quail, and to study the clinical effect of coccidiosis on these birds. 50 dropping samples were collected from 10 Japanese quail farms in and around Bhubaneswar, Odisha, India, including the central poultry development organization. Dead birds were collected for post mortem and histopathological examinations. Some farms appeared normal, but others showed the clinical signs of coccidiosis. Dead birds in post mortem examination showed enteritis with watery mucoid contents and ballooning in the small intestine and ceca. All collected samples were Eimeria positive. Three Eimeria species were isolated; E. bateri (58\%), E. uzura $(86 \%)$, and E. tsunodai (42\%). Three patterns of infection were observed; single infection with $E$. uzura (42\%), single infection with E. bateri (16\%), and mixed infection by the three species (42\%). Results indicated that coccidiosis is one of the most predominant diseases affecting Japanese quail farms, and that effective control and management practices are required to overcome this problem.

Keywords: Japanese quail, coccidiosis, Eimeria bateri, Eimeria uzura, Eimeria tsunodai

\section{Introduction}

Quail production can be regarded as a branch of the modern poultry industry. Meat and egg production are the most common reasons for raising these birds ${ }^{[1]}$. Japanese quails (Coturnix coturnix japonica) were originated from Asia, North Africa, and Europe. They were an important model for aviculture because of the increased consumption of exotic eggs and meats. They were regarded as a substitute for chicken production ${ }^{[2]}$.

Coccidiosis resulted in mild and nonspecific clinical signs, and the natural infection was regarded as a subclinical infection, but it was regarded as a limiting factor for the quail industry as a result of the endogenous stages of the parasite that associated with intestinal lesions. The endogenous stages found in the small intestine of Japanese quail were assumed to be the developmental stages of E. bateri and E. uzura, while the species noticed in the ceca was supposed to be E. tsunodai ${ }^{[3]}$. Clinical coccidiosis causes lesions and mortalities, while subclinical one results in loss of performance due to disorder in the intestinal function ${ }^{[4]}$. The economic impact of coccidiosis is attributed to the reduction in animal production as a depressed growth rate, higher feed conversion ratio, and increased mortality ${ }^{[5]}$. Coccidiosis is the most predominant parasitic disease in quails ${ }^{[6]}$.

Young Japanese quails experimentally infected with E. bateri showed anorexia, depression, mucoid and watery dropping, and that weight means were mildly reduced on day 3 postinfection ${ }^{[7]}$. Clinical symptoms of $E$. tsunodai were characterized by watery diarrhea on day 4 post-infection. A bloody cecal lesion was found on day 5 to 8 post infection, while bloody dropping was more visible on days 5 and 6 post-infection, and most of the mortalities were seen at this period. A lethargic anemic condition with anorexia was present. These clinical findings were similar to those of $E$. tenella in chickens ${ }^{[8]}$. Coccidiosis had adverse effects on both egg production and fertility in bobwhite quails ${ }^{[9]}$. Coccidiosis caused by E. uzura, before sexual maturation, had short term and long term effects on reproductive development and performance ${ }^{[10]}$. Diarrhea was the only observed clinical finding, and the main manifested lesion was cecal ballooning without bloody exudate in the lumen ${ }^{[11]}$. 
E. tsunodai was highly pathogenic and caused signs and lesions of cecal enteritis. The process from the production of the first generation schizont to the formation of the oocysts took place within the ceca ${ }^{[12]}$. E. bateri was the most successful regarding transmission in mixed infections, depending on shedding a greater number of oocysts. The prepatent periods of Eimeria spp. in experimentally inoculated Japanese quails were 4 days for E. bateri, but 5 days for E. uzura and E. tsunodai ${ }^{[2]}$. Desquamation of intestinal mucosa and cecal necrosis were observed in Japanese quails infected with Eimeria species. Developmental stages of Eimeria particularly merozoites and schizonts were noticed in the intestinal epithelium. Schizonts were found in the caecum accompanied with desquamation and necrosis of epithelial lining ${ }^{[11]}$.

The most common Eimeria species isolated from Japanese quails in Brazil were: E. bateri, E. uzura, E. tsunodai, and E. fluminensis [13]. A $27 \%$ total coccidial infection rate was recorded in Japanese quail farms in Egypt ${ }^{[14]}$. The total coccidial infection rate in Japanese quail farms in Saudi Arabian was $29 \%{ }^{[15]}$. Three Eimeria species were isolated from mosul, Iraq; E. tsunodai (44.8\%), E. uzura (34.5\%), and E. bateri $(24.1 \%)^{[16]}$. Four Eimeria species were recorded in Baghdad; E. bateri (66.11\%), E. fluminensis (38.33\%), E. tsunodai $(45 \%)$, and E. uzura $(23.88 \%){ }^{[17]}$. A coccidial infection rate of $40.7 \%$ was recorded in Japanese quail farms in Egypt ${ }^{[18]}$.

Coccidiosis is considered as one of the most common diseases affecting Japanese quail farms. Till now there is no report about Japanese quail coccidiosis in Odisha state. Therefore, studies on quail coccidiosis management through diagnosis by clinical diagnosis, and isolation and identification of different Eimeria species are very important issues for the improvement of quail production.

\section{Materials and Methods}

\subsection{Collection of dropping samples}

Fifty dropping samples were collected from the litter in plastic screw-capped cups from 10 Japanese quail farms in and around Bhubaneswar, including the central poultry development organization (CPDO), Bhubaneswar, Odisha, India during the period from June 2019 to December 2019. Quails were clinically examined.

Samples were sent in the icebox to the laboratory of the Department of Veterinary Clinical Medicine, College of Veterinary Science and Animal Husbandry, Odisha University of Agriculture and Technology, and examined by direct smear ${ }^{[19]}$, and by floatation technique under the light microscope (10X and 40X) ${ }^{[20]}$.

\subsection{Post mortem examination of dead birds and histopathological examination \\ Dead birds were collected for post mortem examination and detection of coccidial lesions in the intestine and cecum. Contents and mucosal scrapings were taken from Intestines and ceca for microscopic examination to detect oocysts and developmental stages of Eimeria. Specimens from intestines and ceca were taken in $10 \%$ formal saline solution for histopathological examination.}

\subsection{Isolation and identification of Eimeria from dropping samples}

2.3.1 Preparation of samples and oocyst concentration

Dropping samples were collected and emulsified in tap water then passed through a wire mesh screen. The emulsion was left to sediment for 15-20 minutes. The supernatant fluid was discarded gently. Sediment was rewashed several times and concentrated by centrifugation for 5 minutes at 1500 r.p.m ${ }^{[21]}$.

\subsubsection{Sporulation of oocyst}

The freshly collected oocysts were suspended in a $2.5 \%$ freshly prepared potassium dichromate solution and incubated at room temperature (average $25^{\circ} \mathrm{C}$ ) for few days (3-7 days) for sporulation [22]. In wide Petri dishes, oocysts were incubated with not more than $0.5 \mathrm{~cm}$ depth of potassium dichromate solution. Frequent aeration was done by shaking the suspension twice daily for few minutes ${ }^{[23]}$. The sporulation time of oocysts was calculated.

\subsubsection{Harvesting and preservation of sporulated oocysts}

Eimeria oocysts were harvested according to the methods described previously ${ }^{[24,25]}$ then preserved in $2.5 \%$ potassium dichromate solution at $4^{\circ} \mathrm{c}$.

\subsubsection{Samples examination and identification of different Eimeria isolates}

Oocysts examination was done by flotation technique and microscopic examination ${ }^{[26]}$. Identification was done under the light microscope (40X and 100X) beside morphometric identification that was done by calibrated ocular micrometer [27]. For measurements, at least one hundred oocysts were measured. Identification relied on morphological characteristics such as (oocyst shape and size, sporocyst size and shape, presence or absence of micropyle, polar granules, oocystic and sporocystic residium, and stieda body of sporocyst) according to the identification guides described previously ${ }^{[2,3,13]}$.

\section{Results and Discussion}

\subsection{Clinical examination of Japanese quail farms and} histopathological results

Most of the examined birds appeared normal, but the quails in some farms showed ruffled appearance, thin weak breast muscle, and knife-edged keel bone with dropping was wet coffee-colored or tinged with blood and mucus. Clinical signs were more severe in young age quails than adults. Similarly, young Japanese quails infected by $E$. bateri showed ruffled appearance, thin weak breast muscle, and wet mucoid dropping ${ }^{[7]}$.

Dead birds in post mortem examination showed enteritis with watery mucoid contents, ballooning in the small intestine, congestion of intestine, and thickened intestinal mucosa (Fig. 1). Similar results were previously reported regarding intestinal coccidiosis in Japanese quail ${ }^{[18]}$. Japanese quails infected by cecal coccidiosis (E. tsunodai) had thin weak breast muscle, knife-edged keel bone, and wet coffee-colored dropping which sometime was tinged with blood and mucus. In post mortem examination, ballooning (Fig. 2) and watery mucoid contents, sometime tinged with blood, were found in the ceca. Similarly, a lethargic anemic condition with anorexia was observed in Japanese quails infected by $E$. tsunodai $^{[8]}$. Diarrhea was the only observed clinical finding, and the main manifested lesion was cecal ballooning without bloody exudate in the lumen ${ }^{[11]}$.

Developmental stages and non-sporulated oocysts of Eimeria were detected in the mucosal scraping of intestines (Fig. 3). Histopathological examination revealed necrosis and desquamation of intestinal mucosal villi with presence of 
developmental stages of Eimeria accompanied by inflammatory cells infiltration and edema (Fig. 4). Cecum showed necrosis of villous epithelium with presence of developmental stages of E. tsunodai, inflammatory cells in the sub-mucosa, and mucus on the mucosal surface (Fig. 5). Similar findings were previously reported ${ }^{[3]}$.

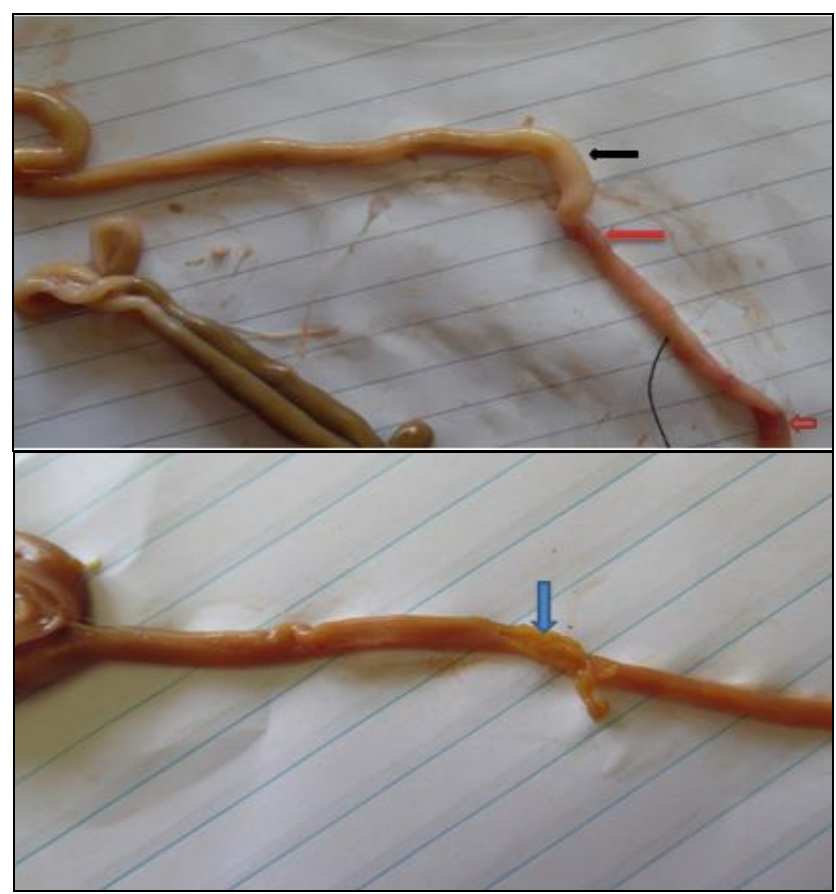

Fig 1: Ballooning (black arrow) and congestion (red arrows) in the ileum of Japanese quail infected by intestinal coccidiosis (up), and thickening of intestinal mucosa (blue arrow) (down).

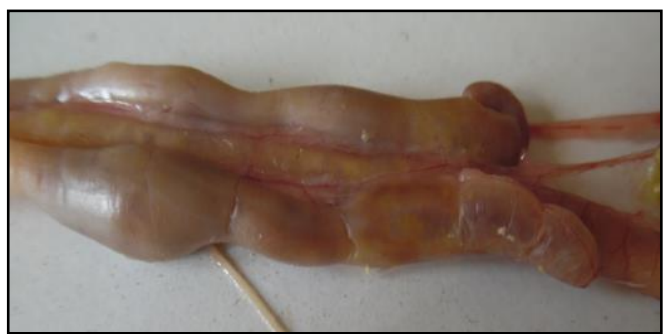

Fig 2: Ballooning in the ceca of a Japanese quail infected by cecal coccidiosis (E. tsunodai).

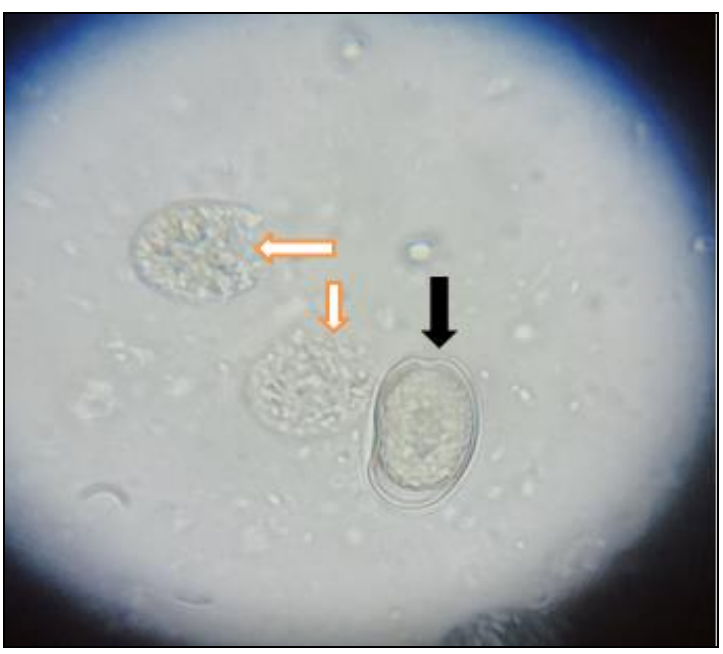

Fig 3: Ruptured schizonts (white arrows) and a non-sporulated oocyst (black arrow) of $E$. bateri in a direct smear of mucosal scraping from the duodenum of a Japanese quail.

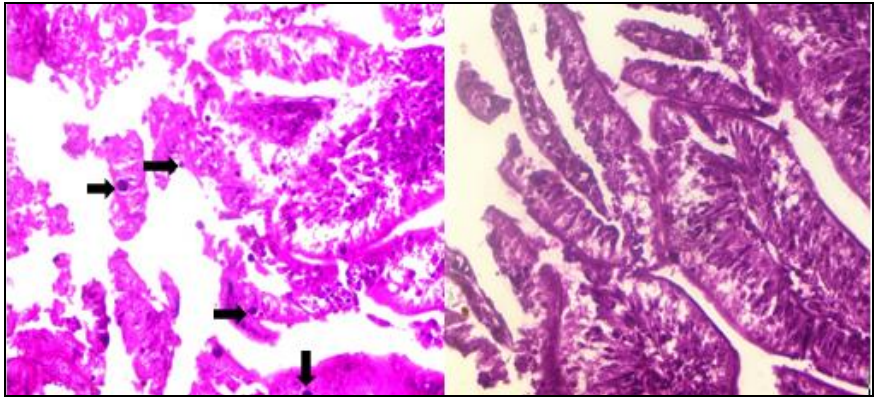

Fig 4: Necrosis and desquamation of mucosal villi of small intestine with presence of oocysts (arrows) of E. bateri and inflammatory cells infiltration (H\&E, 40x).

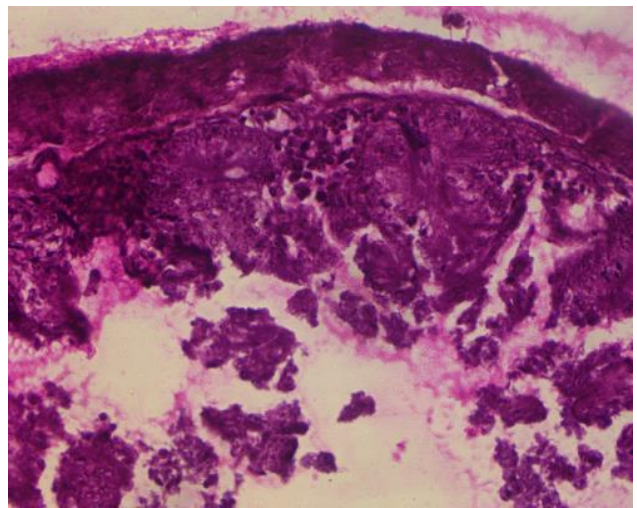

Fig 5: Necrosis of the cecal villous epithelium with presence of few oocysts of E. tsunodai and inflammatory cells in the sub-mucosa, and mucus on the mucosal surface (H\&E, 40x). 


\subsection{Prevalence of coccidial infection}

All collected samples in our study were Eimeria positive. This is supported with that coccidiosis is the most predominant parasitic disease in quails ${ }^{[6]}$.

On the other hand, a $27 \%$ total coccidial infection rate was recorded in Japanese quail farms in Egypt ${ }^{[14]}$, and a $29 \%$ total coccidial infection rate was reported in Japanese quail farms in Saudi Arabian ${ }^{[15]}$.
This difference in the the infection rate may be attributed to the difference in the geographical areas and in the systems of using of anticoccidial agents.

Concerning the site of infection, intestinal coccidiosis represented 58\% (29/50), cecal coccidiosis (E. tsunodai) alone was absent, while infection by both intestinal and cecal species was $42 \%(21 / 50)$ (Table 1).

Table 1: Infection rate according to the site of infection.

\begin{tabular}{|c|c|c|c|c|}
\hline Site of infection & $\begin{array}{c}\text { Only cecal infection } \\
(\text { E. tsunodai })\end{array}$ & $\begin{array}{c}\text { Only intestinal infection } \\
(\text { E. bateri and } \text { E. uzura })\end{array}$ & $\begin{array}{c}\text { Mixed infection } \\
(\text { cecum + intestine) }\end{array}$ & $\begin{array}{c}\text { Total positive } \\
\text { samples }\end{array}$ \\
\hline No. of samples & 0 & 29 & 21 & 50 \\
\hline Percentage (\%) & $0 \%$ & $58 \%$ & $42 \%$ & 50 \\
\hline
\end{tabular}

\subsection{Identification of the isolated Eimeria species}

Eimeria isolates were morphologically identified as E. bateri (58\%), E. uzura (86\%), and E. tsunodai (42\%) (Table 2).
These species are very common in Japanese quail farms worldwide, and they were isolated and described with similar morphological characters in previous studies ${ }^{[2,3,16,28]}$.

Table 2: Infection rate of each Eimeria species.

\begin{tabular}{|c|c|c|c|c|}
\hline Species & E. bateri & E. uzura & E. tsunodai & Total positive samples \\
\hline No. of cases & 29 & 43 & 21 & 50 \\
\hline Percentage (\%) & $58 \%$ & $86 \%$ & $42 \%$ & 50 \\
\hline
\end{tabular}

\subsubsection{E. bateri}

The sporulated oocysts were ovoidal to ellipsoidal, measured $22-30 \mu \mathrm{m}$ by $15-21.5 \mu \mathrm{m}$ with a more common range $25 \times 20$ $\mu \mathrm{m}$ and a shape index 1.2-1.5 (1.35). The oocyst wall was smooth bilayered (colorless outer layer and brownish inner one). One to two refractive polar granules were present. The micropyle and residual body of oocyst were absent. The sporocysts were ovoid, measured $10-13.2 \mu \mathrm{m}$ by $6.3-8 \mu \mathrm{m}$ with a more common range $(12.5 \times 7.5 \mu \mathrm{m})$. They had a nipple like stieda body and a prominent rounded sub stieda body. The sporocyst residual body was present as small granules dispersed among the sporozoites which were in pairs with refractive globules visible in the enlarged extremity (Fig. 6) (Table 3) (Chart 1).

\subsubsection{E. uzura}

The sporulated oocysts were ovoidal to ellipsoidal in shape, measured $18-27.5 \mu \mathrm{m}$ by $15-20.1 \mu \mathrm{m}$ with a more common range of $22.8 \times 17.5$ and a shape index of $1.1-1.5$ (1.3). The oocyst wall was smooth and bilayered (colorless outer layer and brownish inner one). One to four refractive polar granules were present (sometimes with a massive aspect not refractive). The micropyle and residual body of oocyst were absent. The sporocysts were ovoid to elongate, measured 11-
$13.9 \mu \mathrm{m}$ by $5.2-7 \mu \mathrm{m}$ with a more common range of $12.5 \times 6.25 \mu \mathrm{m}$. They had a piriform or knob-like or half-moon shape stieda body and a prominent rounded sub stieda body. The residual body of sporocysts was present as small granules dispersed among sporozoites which were in pairs with refractive globules visible in the enlarged extremity (Fig. 7) (Table 3) (Chart 1).

\subsubsection{E. tsunodai}

The sporulated oocysts were spherical to ellipsoidal in shape, measured $15.2-22.5 \mu \mathrm{m}$ by $14-18.9 \mu \mathrm{m}$ with a more common range of $20-15 \mu \mathrm{m}$ and 1.3 shape index. The oocyst wall was smooth bi-layered (colorless outer layer and brownish inner one) with one flattened end in some oocysts. One to four refractive polar granules were present. The micropyle and residual body of oocyst were absent. The sporocysts were ovoid, measured $10-12 \mu \mathrm{m}$ by 5-6 $\mu \mathrm{m}$ with a more common range of $10 \times 5 \mu \mathrm{m}$. They had a finer end where a small triangular or nipple-like stieda body projected and a rectangular, barely discernible sub stieda body. The residual body of sporocysts was present as small granules dispersed among sporozoites which were in pairs with refractive globules visible in the enlarged extremity (Fig. 8) (Table 3) (Chart 1).

Table 3: Morphological characteristics of different isolated Eimeria oocysts

\begin{tabular}{|c|c|c|c|c|c|c|c|c|c|c|}
\hline & \multicolumn{5}{|c|}{ Oocyst } & \multicolumn{5}{|c|}{ Sporocyst } \\
\hline & Shape & $\begin{array}{l}\text { Length }(\mu) \\
(\text { more } \\
\text { common) }\end{array}$ & $\begin{array}{l}\text { Width }(\mu) \\
(\text { more } \\
\text { common) }\end{array}$ & \begin{tabular}{|c|} 
Shape \\
index \\
(more \\
common)
\end{tabular} & $\begin{array}{c}\text { Polar } \\
\text { Granules }\end{array}$ & Shape & $\begin{array}{l}\text { Length }(\mu) \\
(\text { more } \\
\text { common) }\end{array}$ & $\begin{array}{l}\text { width }(\mu) \\
(\text { more } \\
\text { common) }\end{array}$ & $\begin{array}{c}\text { Stieda } \\
\text { Body }\end{array}$ & $\begin{array}{l}\text { Sub-stieda } \\
\text { Body }\end{array}$ \\
\hline E. bateri & $\begin{array}{l}\text { Ovoidal to } \\
\text { ellipsoidal }\end{array}$ & $\begin{array}{c}22-30 \\
(25)\end{array}$ & $\begin{array}{c}15-21.5 \\
(20)\end{array}$ & $\begin{array}{c}1.2-1.5 \\
(1.35)\end{array}$ & 1-2 refractive & \begin{tabular}{|c|} 
Ovoida \\
1
\end{tabular} & $\begin{array}{c}10-13.2 \\
(12.5)\end{array}$ & $\begin{array}{l}6.3-8 \\
(7.5)\end{array}$ & Nipple-like & $\begin{array}{l}\text { Prominent, } \\
\text { rounded }\end{array}$ \\
\hline E. uzura & $\begin{array}{c}\text { Sub spherical } \\
\text { to ovoidal to } \\
\text { ellipsoidal }\end{array}$ & $\begin{array}{c}18-27.5 \\
(22.8)\end{array}$ & $\begin{array}{c}15-20.1 \\
(17.5\end{array}$ & $\begin{array}{c}1.1-1.5 \\
(1.3)\end{array}$ & $\begin{array}{c}1-4 \text { refractive, } \\
\text { sometimes with } \\
\text { massive non- reactive } \\
\text { aspect }\end{array}$ & $\begin{array}{c}\text { Ovoida } \\
1 \text { to } \\
\text { elongat } \\
\mathrm{e}\end{array}$ & $\begin{array}{c}11-13.9 \\
(12.5)\end{array}$ & $\begin{array}{l}5.2-7 \\
(6.25)\end{array}$ & $\begin{array}{l}\text { Piriform or } \\
\text { knob-like or } \\
\text { half-moon }\end{array}$ & $\begin{array}{l}\text { Prominent, } \\
\text { rounded }\end{array}$ \\
\hline $\begin{array}{c}E . \\
\text { tsunodai }\end{array}$ & $\begin{array}{l}\text { Spherical to } \\
\text { ellipsoidal }\end{array}$ & $\begin{array}{c}15.2-22.5 \\
(20)\end{array}$ & $\begin{array}{c}14-18.9 \\
(15)\end{array}$ & 1.3 & $\begin{array}{c}1-4 \\
\text { Refractive }\end{array}$ & Ovoida & $\begin{array}{c}10-12 \\
(10)\end{array}$ & $\begin{array}{l}5-6 \\
(5)\end{array}$ & $\begin{array}{c}\text { Small } \\
\text { triangular or } \\
\text { nipple-like }\end{array}$ & $\begin{array}{c}\text { Rectangular, } \\
\text { barely } \\
\text { discernible }\end{array}$ \\
\hline
\end{tabular}


There were three patterns of infection: single infection with $E$. bateri $(16 \%[8 / 50])$, single infection with E. uzura $(42 \%$
[21/50]), and mixed infection by the three species (42\% [21/50]) (Table 4).

Table 4: Patterns of infection

\begin{tabular}{|c|c|c|c|c|}
\hline Species & Single infection with $\boldsymbol{E}$. bateri & Single infection with $\boldsymbol{E}$. uzura & Mixed infection with the 3 species & Total positive samples \\
\hline No. of samples & 8 & 21 & 21 & \\
\hline Percentage (\%) & 16 & 42 & 42 & 50 \\
\hline
\end{tabular}

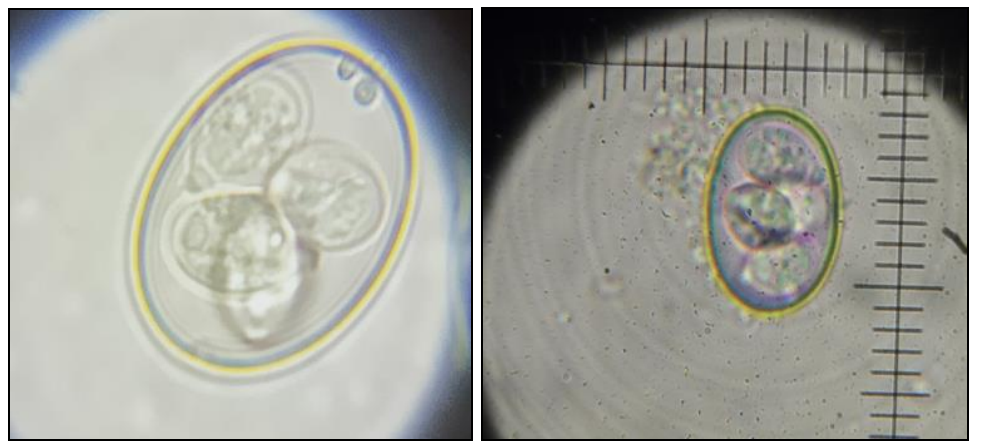

Fig 6: E. bateri sporulated oocyst in saturated salt solution at $100 \mathrm{x}$ (left), and 40x by calibrated micrometer (right).
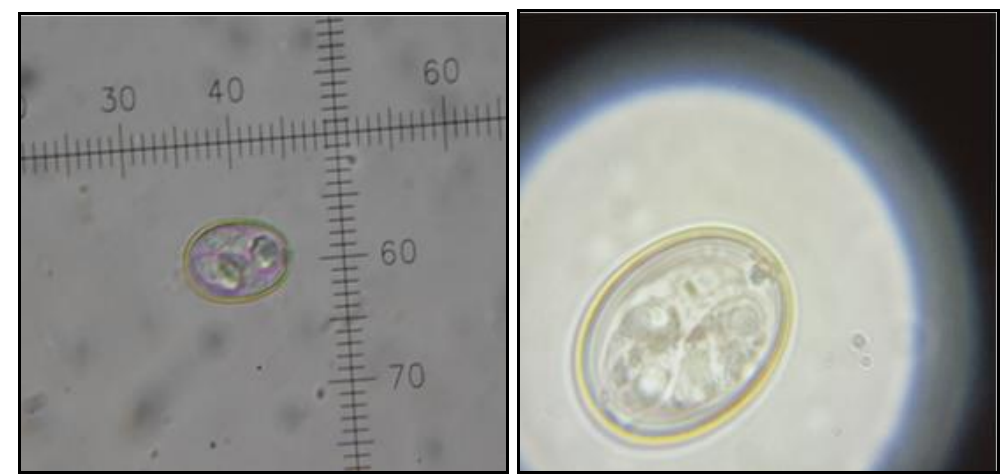

Fig 7: E. uzura sporulated oocyst in saturated salt solution at 100X (right), and 40X by calibrated micrometer (left).
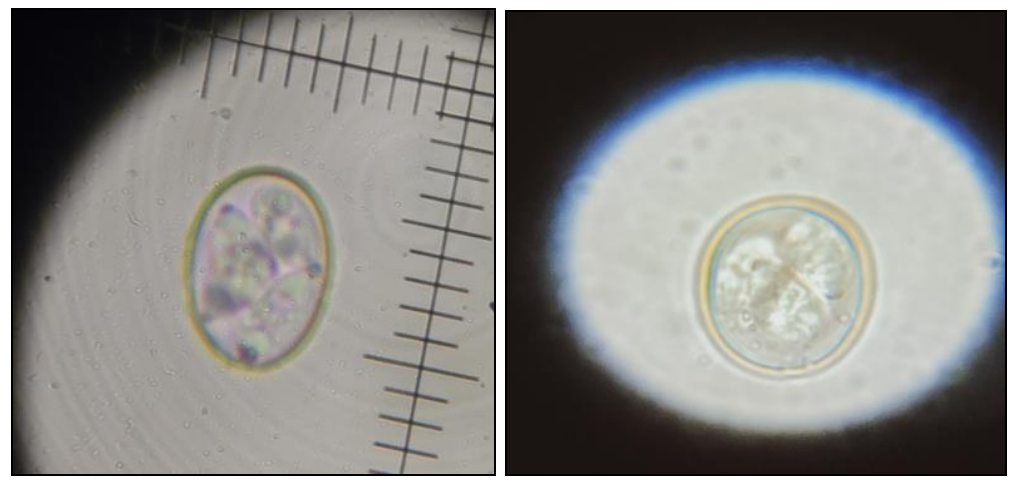

Fig 8: E. tsunodai sporulated oocyst in saturated salt solution at 100X (right), and 40X by calibrated micrometer (left).

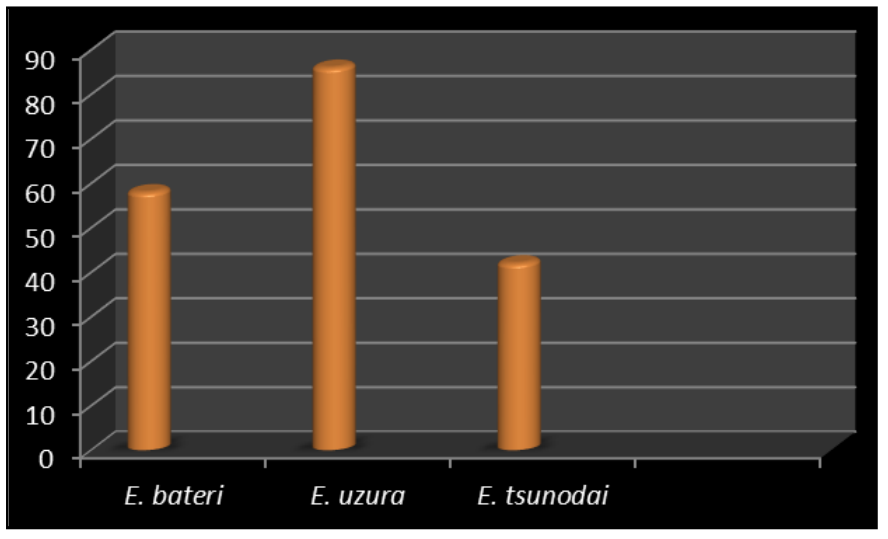

Chart 1: Infection rate of different Eimeria species.
Coccidiosis causes a great impact on quail production and invades the Japanese quail farms. Therefore, it is so important to conduct further studies on quail coccidiosis including; biology, epidemiology, immunization, and treatment with different anticoccidial drugs and herbal products.

\section{Conclusion}

Coccidiosis is one of the major problems present in Japanese quail farms. It affects clinically and economically on quail production including weight gain, feed conversion efficacy, and mortalities. The most predominant Eimeria species infect Japanese quail were E. bateri, E. uzura and E. tsunodai. The infection severity and rate increased at young age compared to adults. E. tsunodai was more pathogenic than E. bateri and E. uzura. 


\section{Acknowledgement}

I need to convey me deepest gratitude to the director of CPDO, Bhubaneswar, Odisha, India for providing facilities for samples collection.

\section{References}

1. Sreeranjini AR, Lyyangar MP, Pramod KD. Histological study on the fibrous architecture of kidney and ureter of Japanese quail (Coturnix coturnix japonica). Tamilnadu. Journal of Veterinary and Animal Sciences 2010;6(2):107-110.

2. Berto BP, Borba HR, Lima VM, Flausino W, TeixeiraFilho WL, Lopes CWG, et al. Eimeria spp. from Japanese quails (Coturnix japonica): new characteristic features and diagnostic tools Pesquisa Veterinaria Brasileira 2013;33(12):1441-1447.

3. Teixeira M, Teixeira-Filho WL, Lopes CWG. Coccidiosis in Japanese quails (Coturnix japonica): Characterization of a Naturally Ocurring Infection in a Commercial Rearing Farm, Brazilian Journal of Poultry Science 2004;6(2):129-134.

4. Marien M, Gussem DM. Coccidiosis rotation programmes are a must! Poultry World 2007;23(7):3435.

5. Peek HW, Landmanab WJM. Coccidiosis in poultry: anticoccidial products, vaccines and other prevention strategies. Veterinary Quarterly 2011;31(3):143-161.

6. Gesek M, Welenc J, Tylicka Z, Otrocka-Domagała I, Paździor K, Rotkiewicz A, et al. Pathomorphological changes in the alimentary system of Japanese quails naturally infected with Eimeria tsunodai. Bulletin of the Veterinary Institute in Pulawy 2014;58(1):41-45.

7. Norton CC, Peirce MA. The life cycle of Eimeria bateri (Protozoa: Eimeriidae) in the Japanese quail (Coturnix japonica). The Journal of protozoology 1971;18(1):5762.

8. Tsutsumi Y, Tsunoda K. Pathogenicity of Eimena tsunodai from Japanese quails (Cotumix cotumix japonica) and susceptibility of the coccidium to some drugs, The Japanese journal of veterinary science 1972;34(3):115-121.

9. Ruff MD, Wilkins GC, Chute MB. Prevention of coccidiosis in bobwhites by medication. Poultry science 1987;66(9):1437-1445.

10. Ruff MD, Nabi MA, Clarke RN, Mobarak M, Ottinger MA. Effect of coccidiosis on reproductive maturation of male Japanese quail. Avian diseases 1988;32:41-45.

11. Umar HA, Lawal IA, Okubanjo OO, Wakawa AM. Morphometric identification, gross and histopathological lesions of Eimeria species in Japanese quails (Coturnix coturnix japonica) in Zaria, Nigeria. Journal of veterinary medicine 2014, 1-6

12. Tsutsumi Y. Eimeria tsunodai n. sp. (Protozoa: Eimeriidae). A cecael coccidium of Japanese quails (Coturnix japonica). The Japanese journal of veterinary science 1972; 34(1):1-9.

13. Teixeira M, Lopes CWG. Species of the genus Eimeria (Apicomplexa: Eimeriidae) from Japanese quails (Coturnix japonica) in Brazil and E. fluminensis for the preoccupied E. minima of this quail, Revista Brasileira de Ciências Veterinárias 2002;9(1):53-56.

14. Abdel-Hadi DS. Studies on Eimeria sp. (Coccidia) infecting quail "Coturnix japonica" in Egypt. M.V.Sc. Thesis. Zoology department, Faculty of Science, Cairo
University, Bani-suef branch, Bani-suef, Egypt 2008.

15. Bashtar AR, Abdel-Ghaffar F, Al-Rasheid KA, Mehlhorn H, Al Nasr I. Light microscopic study on Eimeria species infecting Japanese quails reared in Saudi Arabian farms. Parasitology research 2010;107(2):409-416.

16. Mohammad NH. A study on the pathological and diagnosis of Eimeria species infection in Japanese quail. Basrah Journal of Veterinary Research 2012;11(1):318-333.

17. Al-Saeedy HY, AL-Rubaie HM. Epidemiological study of coccidiosis in quail in Baghdad city. Journal of Kerbala University 2014;12(4):42-49.

18. Elmorsy MA. Studied on quail coccidiosis. M.V.Sc. Thesis. Poultry and Rabbit Diseases Department, Faculty of Veterinary Science, Mansoura University, Mansoura, Egypt 2017.

19. Urquhart GM, Armour J, Duncan JL, Dunn AM, Jennings FW. Veterinary Parasitology. 2nd edn, Black Well Science Ltd., Oxford 2003, 276.

20. Duszynski DW, Wilber PG. A guideline for the preparation of species descriptions in the Eimeriidae. The Journal of parasitology 1997;83:333-336.

21. Soulsby EJL. Helminthes, arthropods and protozoa of domestic Animals. $6^{\text {th }}$ Edition of of Mönnig's Veterinary helminthology and entomology, Bailliere-Tindall \& Cassel Ltd, London, UK 1968.

22. Adefolabi TK, Chiejina S. The faecal coccidial oocyst output of adult small ruminants in Nigeria. Nigerian Veterinary Journal 1987;16:1-6.

23. Long PL. Maintenance of intestinal protozoa in vivo with particular reference to Eimeria and Histomonas. In: Taylor A, Muller R (Eds.): Isolation and maintenance of Parasites in vivo. Blackwell Scientific Publications, Oxford and Edinburgh, United Kingdom 1971, 65-73.

24. Shirley MW. Eimeria species and strains of chicken. In: Braun R, Eckert J (Eds.): Biotechnology Guidelines on Techniques in Coccidiosis Research. European Commission, Luxembourg 1995, 1-24.

25. El-Nahas AF, Awad AM, Abu-Akkada SS. Genetic variation among five Egyptian field isolates of Eimeria tenella detected by random amplified polymorphic DNA assay. Global Veterinaria 2011;7(3):256-263.

26. Urquhart GM, Armour J, Dunkan JL, Dunn AM, Jennings FW. Veterinary Parasitology. Longman Sc. \& Tech., Harlow, United Kingdom 1987, 150.

27. Henddrix CM, Robinson Ed. Diagnostic Parasitology for Veterinary Technicians. $3^{\text {rd }}$ ed, Mosby, Missouri, United States 2006, 232-236.

28. El-Morsy MA, Abou El-Azm KI, Awad SS. Efficacy of some anticoccidial drugs on experimentally induced cecal coccidiosis (E. tsunodai) in Japanese quails. Egyptian Journal of Veterinary Science 2016;47(2):165-177. 